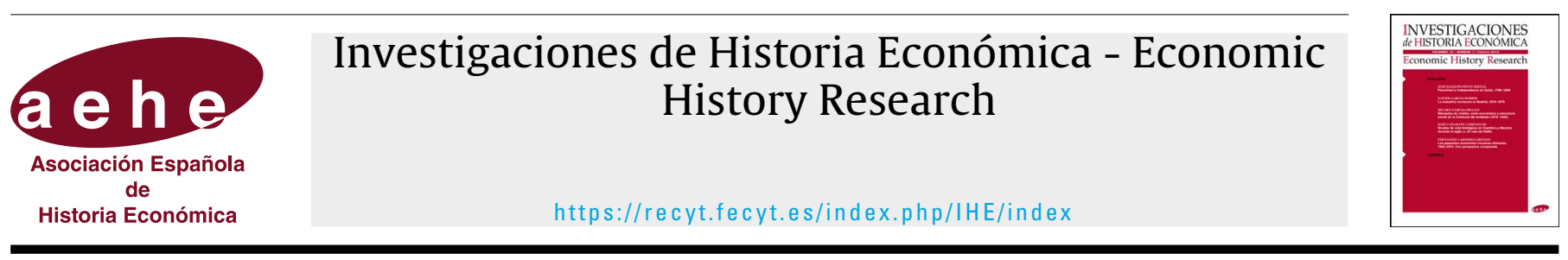

Reseña

\section{Vicente Pinilla, Luis Germán y Agustín Sancho. El transporte público en Zaragoza. Zaragoza, Prensas de la Universidad de Zaragoza, 2018, 264 págs., ISBN: 9788417358952.}

Desde la Revolución Industrial inglesa la demanda de movilidad ha protagonizado una revolución «silenciosa» que tiene en la específicamente urbana uno de sus capítulos más singulares. No supone casualidad alguna, por lo tanto, que el contexto del excepcional crecimiento demográfico que ha caracterizado esta etapa -el propio de la población urbana, que desde 2010 suma ya más de la mitad- provocara que en los mismos orígenes de la configuración de las ciudades modernas surgieran los primeros sistemas de transporte. Igualmente compresible resulta que estos hayan desempeñado, desde entonces, un papel decisivo en la extensión y sostenibilidad de las mismas. Y habida cuenta de su complejidad, entra dentro de lo lógico, por último, que la historia de la movilidad se haya incorporado como una más de las áreas de conocimiento en las que se ha segmentado nuestra disciplina.

Aunque El transporte público en Zaragoza se estructura cronológicamente, cada una de sus cuatro etapas es introducida, primero, con una descripción de lo que estaba ocurriendo en el resto de los países industrializados, de tal suerte que estas «ojeadas» constituyen por sí mismas una excelente síntesis de la historia del transporte urbano contemporáneo. Y, segundo, con un análisis de la propia transformación sufrida por la ciudad aragonesa según los diferentes ciclos del crecimiento económico que esta experimentó, los cuales, ciertamente, justifican la propia organización de la monografía.

Pero estos ejercicios son mucho más que el pergeño de un contexto o un mero recurso erudito, como ocurre en muchas ocasiones, ya que Vicente Pinilla, Luis Germán y Agustín Sancho tienen el acierto de inducir de ellos las categorías que les hace posible defender su tesis central. A saber, que como en los otros casos, la configuración de la ciudad moderna operó en Zaragoza como una especie de imperativo que obligó a configurar sistemas públicos de transporte que satisficieran la demanda de movilidad para impedir su colapso y que, a la par, actuaron como otro agente conformador más de la propia ciudad.

Tal vez quepa sugerirles, por un lado, que hubiese sido interesante haber elaborado con todas estas miradas un úni- co capítulo. Y, por otro, que hubiese sido pertinente haber disertado sobre las causas que provocaron el fallo del mercado a la hora de garantizar la oferta privada de movilidad urbana y, por consiguiente, que acabara el Estado erigiéndose en su proveedor. No parece ajeno a ello que diferentes cuestiones sociales adquirieran un papel central en los cambios morfológicos de la ciudad y en la evolución de la demanda de movilidad. No está de más hacer hincapié, por lo tanto, en que, si bien las clases burguesas aprovecharon los nuevos sistemas de transporte para ubicarse fuera de su casco histórico, fue la producción de las industrias, que se fueron localizando en su extrarradio, lo que exigió contar con medios de movilidad que permitiesen a los trabajadores llegar a las fábricas.

Una vez analizada esta primera dimensión, los tres autores abordan el estudio de la oferta que, obviamente, constituye el meollo de la monografía. Y para ello acuden al enfoque que proporciona la historia empresarial. En concreto, la de una única concesionaria que prestó el servicio, de la cual reconstruyen su evolución institucional, su oferta -donde ocupan un protagonismo relevante las revoluciones tecnológicas que lo caracterizaron- y su demanda. Pero, sin duda, sus dos novedades más sobresalientes son el análisis que hacen de las relaciones laborales, prácticamente ausente en casi toda la historia empresarial, y el interesante proceso de integración vertical que caracterizó a aquella durante buena parte del periodo estudiado.

Les asiste la razón a los tres historiadores cuando sostienen que una de las fortalezas $-\mathrm{y}$ novedades-del libro reside en que aborda sus análisis en una perspectiva de largo plazo, ya que es el único ejercicio que hace posible comprender en toda su dimensión los cambios acontecidos. Con ser esta una relevante aportación, no es ni la única ni la más destacada, ya que, frente al carácter eminentemente descriptivo que han presentado la mayoría de las obras dedicadas a este tema, El transporte público en Zaragoza supone un solvente análisis que renueva notoriamente la historiografía.

Miguel Muñoz Rubio

Universidad Autónoma de Madrid

https://doi.org/10.33231/j.ihe.2020.01.010 